Vertex flat, slightiy obtusely angled, one-third wider than the middle length, over three-fourths the length of the pronotum, face and facial angle as in signalifrons ; pronotum shorter, over twice wider than long ; clytra equalling the abdomen in the female, slightly longer in the male, shorter than in signatifroms, with a very slight appendix, venation as in cruciatus.

Colour : vertex with the margins, a median stripe and a short transverse bar before the middle always light, the remainder of the disc with a very variable amount of fuscous, fading nut posteriorly into a rust brown ; pronotum irregularly marked with rust brown - in the darker specimens arranged in longitudinal stıipes; elvta palc, subhyaline, the nervures white. a broad. slightly ololique band across the miclde, another before the tip, and spots on the margins of the second and third apical cells fuscous.

Genitalia : female, ultimate rentral segment short, the lateral angles acute, posterior margin roundingly cmarginate either side of a large, acutcly pointed, black tooth, which is cleft nearly to its base ; either side of this troth the oblique finger-like plates are exposed; male valve obrusely angulate, longer than the ultimate segment, plates broad at base, slightly barrowing to the truncate tips, where they are two-thirds the lasal widh, two and one-half times the length of the valve, set obliquely together, forming a trough.

Described from numerous specimens swept from the meadows of the Iittle Beaver, in the mountains west of Fort Collins, Colo.

\title{
CTENUCHA CRESSONANA.
}

In the recent volume published by the British Museum (Natural History), Sir Geo. Hampson refers this species, described by me in 1863 , as the same with $C$. venosa. The material in the British Museum from North America : Texas, Grote and Zeller collections, is all C. venosa. C. Cressonana, from Colorado, is clearly distinct, a larger species more of the type of $C$. virginica, and I can only suppose that unacquaintance with my type has led to the present lumping. I may also add, that it can hardly be settled in the British Museum, whether the. Californian Scepsis Packardi which has lighter linted primaries, and grcater extension of a paler yellow on the head, be a local race of $s$. fulwicollis or not. From analogy in the group, it will probably prove distinct.

Roemer Museum, Hildesheim, Germany.

A. Radchiffe Grote. 